https://doi.org/10.15407/ujpe65.9.741

O. PAVLENKO,${ }^{1}$ O. DMYTRENKO,${ }^{1}$ M. KULISH,${ }^{1}$ A. GAPONOV,${ }^{1}$

N. OBERNIKHINA, ${ }^{2}$ O. KACHKOVSKY,${ }^{3}$ O. ILCHENKO,${ }^{4}$ L. BULAVIN $^{1}$

1 Taras Shevchenko National University of Kyiv

(64, Volodymyrs'ka Str., Kyiv 01601, Ukraine; e-mail: olpavl57@gmail.com)

2 A.A. Bogomolets National Medical University

(13, Tarasa Shevchenka Blvd., Kyiv 01033, Ukraine)

${ }^{3}$ V.P. Kukhar Institute of Bioorganic Chemistry and Petrochemistry, Nat. Acad. of Sci. of Ukraine

(1, Murmans'ka Str., Kyiv 02094, Ukraine)

4 Technical University of Denmark

(Anker Engelunds Vej 1, Bld. 101A, 2800 Kgs. Lyngby, Denmark)

\title{
QUANTUM CHEMICAL MODELING OF THE COMPLEXES OF SQUARAINE \\ DYES WITH CARBON NANOPARTICLES: \\ GRAPHENE, NANOTUBE, FULLERENE
}

\begin{abstract}
The geometry and electronic structure of the complexes of dyes containing various numbers of electron-donor oxygen atoms and carbon nanostructures with various dimensions (fullerene $C_{60}$, carbon nanotube, graphene) have been studied. It is shown that the charge transfer from the dyes to the carbon nanostructures leads to changes in the geometry of carbon nanostructures and the dye chromophores, as well as in the electronic structure of the whole complexes.

Keywords: dyes, carbon nanoparticles, electronic structure.
\end{abstract}

\section{Introduction}

Carbon nanostructures - such as fullerenes, graphene, and nanotubes - are promising materials for numerous applications. Their interaction with organic molecules very often leads to the appearance of new properties that can be adapted to specific tasks. For instance, unlike critically important metals - such as platinum $(\mathrm{Pt})$, gallium $(\mathrm{Ga})$, germanium $(\mathrm{Ge})$, and others [1] - graphene can be easily produced from graphite. Graphene becomes potentially important in various branches of the industry, because the materials on its basis possess high catalytic activity and absorption [2]. They are flexible, which is important for a lot of devices, and light. Their production cost is

(C) O. PAVLENKO, O. DMYTRENKO, M. KULISH,

A. GAPONOV, N. OBERNIKHINA,

O. KACHKOVSKY, O. ILCHENKO, L. BULAVIN, 2020 low. They are easy to be treated and can be manufactured in the form of thin films, impurities in the form of clusters, and so forth. Graphene can be used as photoanodes, electrodes in dye-sensitized solar cells (DSSCs) [3-9].

The folding of a graphene plane into a tube provides the resulting material with a high strength coefficient and good thermal and electrical conductivities. The best efficiency $(>10 \%)$ of DSSCs was achieved for an oriented cell fabricated on the basis of carbon nanotubes. Among the carbon materials used in DSSCs, carbon nanotube $/ \mathrm{TiO}_{2}$ electrodes provide the highest efficiency [10].

Fullerenes $\mathrm{C}_{60}$ are closed carbon clusters with the icosahedral symmetry Ih, which gives rise to an extremely high density of electronic states: the lowest vacant (unoccupied) molecular orbitals (LUMOs) are triply degenerate, whereas the highest occupied 

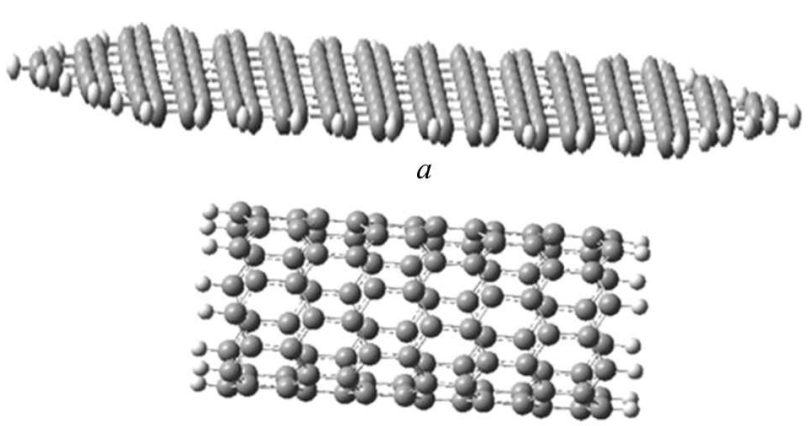

b

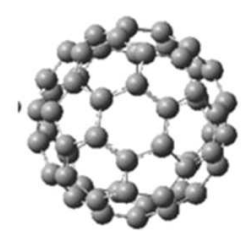

$c$

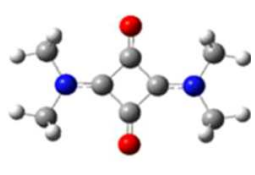

$d$

Fig. 1. Molecular structures of model objects: graphene $(a)$, carbon nanotube $(8,0)(b)$, fullerene $\mathrm{C}_{60}(c)$, and squaraine dye $\mathrm{C}_{8} \mathrm{~N}_{2} \mathrm{O}_{2} \mathrm{H}_{8}(d)$

molecular orbital (HOMO) is five-fold degenerate [11]. Owing to specific peculiarities of their electronic structure, fullerenes were found useful in a huge number of practical applications, in particular, as acceptors in solar cells in which cyclic or linear conjugated molecules are used as donors [12-14]. The sensitivity of a solar cell in various spectral intervals strongly depends on the absorption of a conjugated donor. Significant results were obtained with the help of polymethine dyes, in particular, squaraine dyes, which can be considered as neutral derivatives of ionic polymethine dyes with identical spectral properties. The efficiency of solar energy conversion substantially depends on the nanocomposite architecture and morphology. In particular, the molecular arrangement of donors and fullerenes must provide the overlapping of their $\pi$ conjugate electron systems [15-17].

The study of the interaction between carbon nanoparticles and polymethine dyes invokes a considerable interest, because such molecular systems have significant prospects for their application in the solar energy industry, molecular electronics, and as photosensitizers for photodynamic therapy [12]. Such possibilities are associated with specific features in the electronic structure of carbon nanoparticles and dyes, which can be purposefully modified by allowing their molecules to interact. This restructuring allows the

narrow and intense bands of light absorption of the dyes to be shifted into a desired spectral interval [18].

The scope of applications of polymethine dyes in biomedicine (as probes for clinical analysis) and chemical biology is also growing. The dyes demonstrating the intense fluorescence in the near IR interval are effectively used as probes for in vivo images of, e.g., malignant tumors, because they are able to deeply penetrate into tissues. Biopolymers namely, proteins, antibodies, nucleic acids, and other biostructures - can also bind to dyes by means of the covalent interaction. However, more and more interesting becomes the non-covalent interaction, which is a result of the strong hydrophobic or ionic interaction between such marker dyes and biopolymers, and leads to the formation of stable complexes [19].

The properties of carbon nanostructures and polymethine dyes are successfully combined in nanoelectronics and form a basis for the design of new promising molecular complexes for various applications. This work was aimed at a quantum chemical study of the structure and electronic properties of the complexes of the squaraine dye $\mathrm{C}_{8} \mathrm{~N}_{2} \mathrm{O}_{2} \mathrm{H}_{8}$ with carbon nanostructures of various dimensions and shapes in order to establish the mechanisms of interaction between them.

\section{Research Objects and Quantum Chemical Calculations}

In this work, quantum chemical calculations of the structure of the complexes of the squaraine dye $\mathrm{C}_{8} \mathrm{~N}_{2} \mathrm{O}_{2} \mathrm{H}_{8}$ with the graphene, nanotube, and $\mathrm{C}_{60}$ fullerene objects were performed.

A monolayer sheet of graphene was selected as a two-dimensional object for calculations. It included 204 carbon atoms (Fig. 1, a). A carbon nanotube was modeled as a folded graphene sheet consisting of 112 carbon atoms with a chirality of $(8,0)$ (the semiconductor type) (see Fig. 1, b). In order to correctly account for the valence bonds of the outermost carbon atoms in the graphene plane and the nanotube, those atoms were connected with hydrogen atoms. We also consider the properties of the complex of the indicated dye with a fullerene molecule $\mathrm{C}_{60}$ (Fig. 1,c), which possesses the highest symmetry degree and is the most stable.

In order to study the interaction between dyes and carbon nanostructures, the model squaraine 
dye $\mathrm{C}_{8} \mathrm{~N}_{2} \mathrm{O}_{2} \mathrm{H}_{8}$ was chosen. It consists of a polymethine chromophore and a built-in square ring (Fig. 1,d). This dye in the squaraine functional group contains two oxygen atoms with common electron pairs. Owing to the latter, the dye is an electron donor and can transfer those electrons to other structures, when being excited by light.

Since all considered molecules belong to $\pi$-conjugate systems, the distance between the components before the procedure of complex geometry optimization was put equal to $3.4 \AA$, which is typical of complexes with the stack interaction and containing aromatic cycles. The equilibrium distance between them was calculated in the course of optimization. The optimized molecular geometry of the examined systems was obtained using the semiempirical PM6 method and the density functional method DFT/WB97XD//6-31G(d,p). The parameters of electronic transitions were calculated in the framework of the semiempirical ZINDO and TD-SCF approaches using the software package Gaussian-09 [20]. Like it happens for other non- and semiempirical approximations, no perfect coincidence between calculated and experimental data can be reached. But that will do for a proper analysis of the nature of electronic transitions [21,22].

\section{Results and Their Discussion}

\subsection{Quantum chemical modeling of the interaction between graphene and squaraine dye}

Graphene is a monolayer of carbon atoms, which consists of six-membered rings. The carbon atoms are connected by hybridized $s p^{2}$ bonds into a twodimensional (2D) hexagonal lattice. The length of the bonds between carbon atoms is about $0.142 \mathrm{~nm}$.

For the simulation, we took a finite sheet of graphene consisting of 204 carbon atoms and with hydrogen atoms at its boundary, which substantially polarize the bond lengths of the outermost atoms. The geometric optimization of this graphene sheet is shown in Fig. 2, $a, b$. The distance between the carbon atoms varies from $1.41 \AA$ between the outermost atoms to $1.417 \AA$ between the atoms in the central part of the sheet.

The bond lengths directly depend on the charge distribution over the atoms (squares in Fig. 3). Owing to the presence of hydrogen atoms, each of the

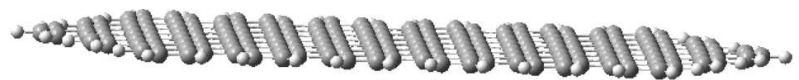

$a$

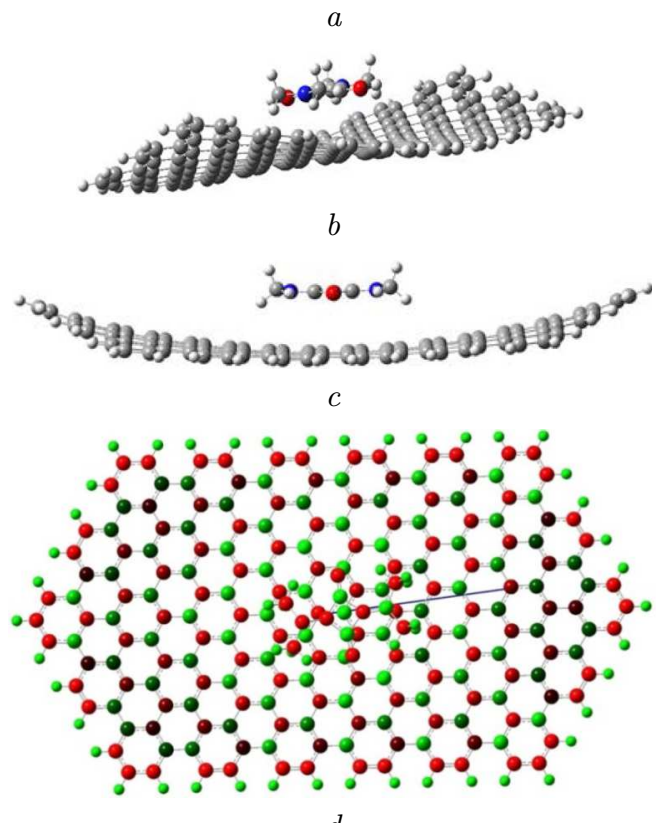

$d$
Fig. 2. Optimized geometry of graphene plane (a) and graphene-dye complex $(b)$. Charge distribution in the graphenedye complex calculated using PM6 $(c)$ and DFT $(d)$ methods. The arrow demonstrates the direction of the dipole moment

neighboring carbon atoms has a substantial negative charge, and those atoms can be ignored. One can see that the enumerated atoms have almost zero charge values, which grow to positive or negative values as the atoms become located closer to the sheet boundary. The selected graphene sheet is flat, and the corresponding dipole moment equals zero. The energy values for the HOMO and LUMO levels were obtained using the density functional method with the indicated basis, and they amount to -5.7 and $-1.8 \mathrm{eV}$, respectively.

After the complex of the dye with the graphene sheet has been formed, the optimized equilibrium distance between the components was determined to equal $3.5 \AA$ A. Owing to the interaction, the charge distribution changes (Fig. 3). The carbon atoms in graphene acquire alternately negative and positive charge values (the charge alternation), which becomes more pronounced, if the optimization is carried out using the PM6 method (Fig. 4, circles). As a result, there appears a dipole moment of $0.4 \mathrm{D}$ (calculated using the DFT method) or 3.6 D (calculated using 

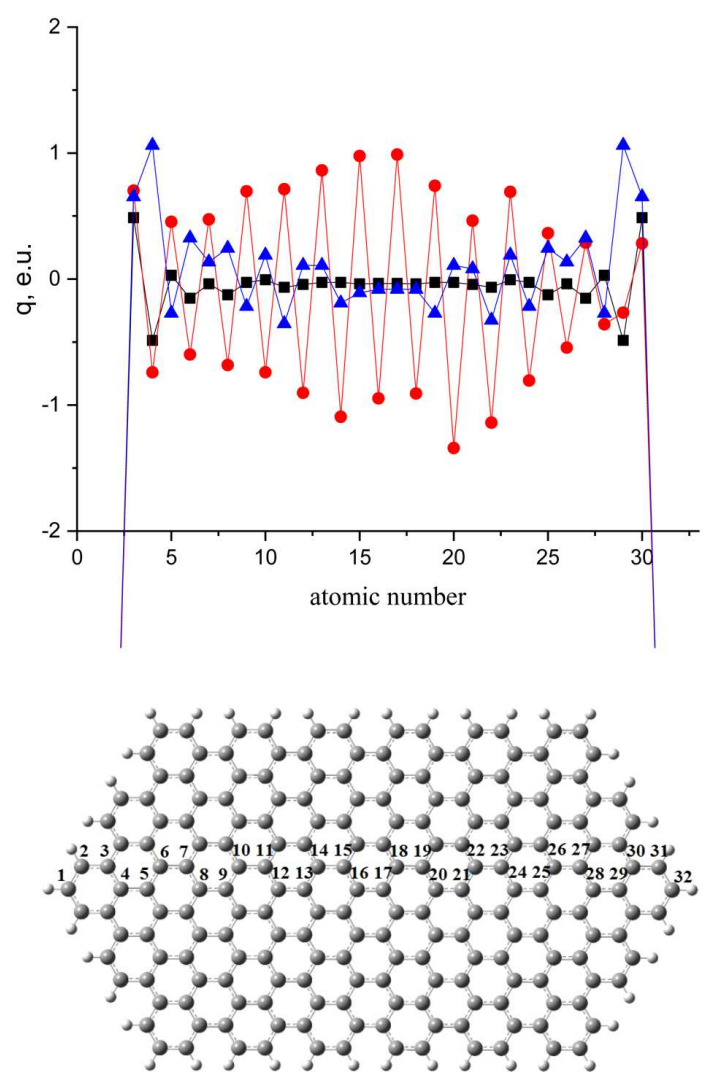

Fig. 3. Charge distributions over the graphene atoms before (squares) and after the formation of the graphene-dye complex calculated using the PM6 (circles) and DFT (triangles) methods. The enumeration of atoms is shown in the lower panel

the PM6 method). The charge alternation obtained in the framework of the PM6 method is much larger in comparison with that obtained using the density functional method, which is typical of those methods.

Such alternating charge distribution, which may probably be a result of the charge transfer from the dye to graphene, manifests itself in a change of the graphene plane geometry in the complex (Figs. 2, $b$ and $c$ ), which is confirmed by both calculation methods. The charge distribution also affects the reconstruction of electronic levels, when the components interact (Fig. 4). From the results of calculations performed using the density functional method, one can see that the dye levels are located at $-6.6 \mathrm{eV}$ for the HOMO and $0.7 \mathrm{eV}$ for the LUMO, whereas the corresponding levels of graphene lie at -1.75 and $-5.65 \mathrm{eV}$, respectively. In the case of graphene, these orbitals are localized at carbon atoms in the central part of the sheet. The orbitals localized at the outermost hydrogen atoms are energetically lower. In comparison with its separate components, there is an insignificant shift of the energy gap in the dye-graphene complex: by $-1.7 \mathrm{eV}$ for the HOMO and $-1.75 \mathrm{eV}$ for the LUMO. The forms of these orbitals are localized at the same atoms as in graphene, but a contribution to them from the electron density of the dye can be observed. The HOMO-2 orbital of the complex is localized at the dye.

The calculations of the excited states of the complex with the help of the ZINDO and TD-SCF methods showed that it is the orbitals localized at the dye chromophore that are responsible for the electronic transition giving the most intense contribution to the absorption spectrum. The absorption maximum shifts from $340 \mathrm{~nm}$ for the dye to $664 \mathrm{~nm}$ for the complex.

\subsection{Quantum chemical modeling of the nanotube-dye complex}

A nanotube characterized by a chirality of $(8,0)$ and consisting of 112 carbon atoms and 16 hydrogen atoms is shown in Fig. 5, a. This nanotube is asymmetric and has polarized bonds at its boundary owing to the presence of hydrogen atoms. Therefore, it has a large dipole moment of $8.5 \mathrm{D}$ (according to results of the DFT method) directed from its center along the axis. The values of the HOMO and LUMO levels obtained with the help of the density functional method with the indicated basis are -4.9 and $-2.4 \mathrm{eV}$, respectively. The energy gap for this nanotube is narrower $(2.6 \mathrm{eV})$ in comparison with that for graphene $(3.9 \mathrm{eV})$.

At the formation of the nanotube-dye complex, a charge redistribution takes place. It results in changes of both the direction and the magnitude (to $8.9 \mathrm{D}$ ) of the dipole moment. The distance between the complex components amounts to $3.4 \AA$.

The complex gap slightly decreases because the LUMO energy changes from $-2.4 \mathrm{eV}$ in the nanotube to $-2.5 \mathrm{eV}$ in the complex. In both cases, the HOMO and LUMO orbitals are localized at the $\mathrm{C}-\mathrm{H}$ bonds of the nanotube (Fig. 6).

The shape of orbitals in the energy gap region does not change, whereas the HOMO-3 level of the dye becomes by $0.1 \mathrm{eV}$ lower in comparison with that in graphene, which should also manifest itself in the spectral characteristics. The results of calculations

ISSN 2071-0194. Ukr. J. Phys. 2020. Vol. 65, No. 9 


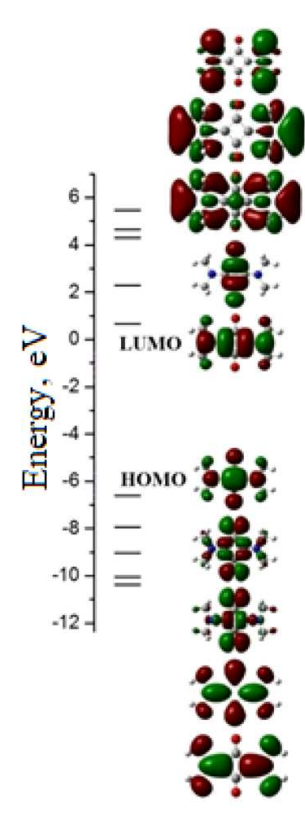

$a$

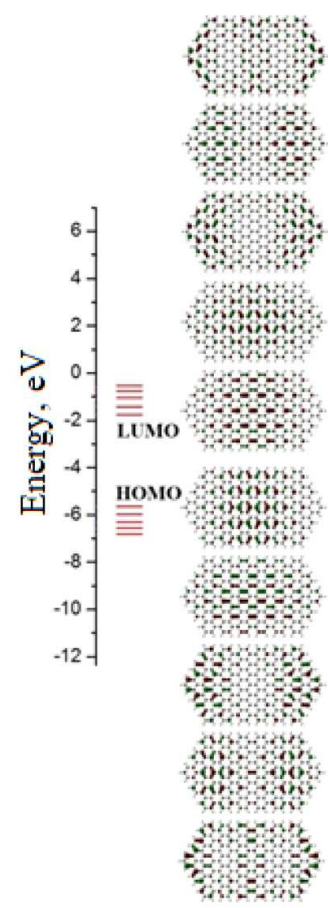

$b$

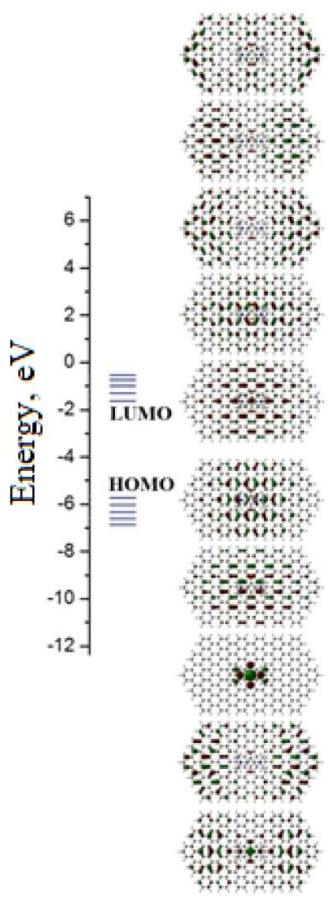

$c$

Fig. 4. The distribution of electronic levels and the shapes of molecular orbitals for $\mathrm{C}_{8} \mathrm{~N}_{2} \mathrm{O}_{2} \mathrm{H}_{8}$ dye $(a)$, graphene $(b)$, and their complex in the energy gap region calculated using the DFT method $(c)$

obtained for the excited states of the dye-nanotube complex show that the latter absorbs light in almost the whole wavelength interval, which requires a further research.

\subsection{Quantum chemical modeling of the $C_{60}$ fullerene-dye interaction}

The $\mathrm{C}_{60}$ fullerenes in the condensed state at room temperature form typical molecular crystals. Their electronic states are energetically identical to their counterparts in an isolated molecule. A specific feature of fullerenes, which is responsible for their electronic properties and their ability to form the intermolecular interaction, is the icosahedral symmetry Ih. As was said in Introduction, the latter provides an extremely high density of electronic states, so that the LUMOs are triply degenerate, and the HOMO is five-fold degenerate. This symmetry prohibits transitions with light absorption or emission between the ground and the first excited singlet state $h_{u} \rightarrow t_{1 u}$ (HOMO-LUMO), so that this optical transition can occur only with the participation of phonons [11].

ISSN 2071-0194. Ukr. J. Phys. 2020. Vol. 65, No. 9

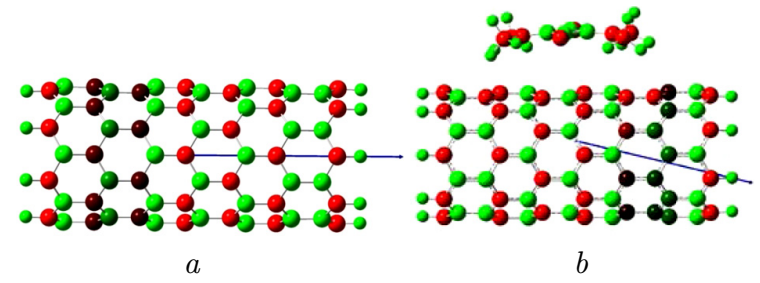

Fig. 5. Geometry of model nanotube $(8,0)(a)$ and dyenanotube complex optimized using the DFT method $(b)$. The arrow demonstrates the direction of the dipole moment

The spherical surface of a $\mathrm{C}_{60}$ molecule contains 20 regular hexagonal and 12 pentagonal elements and resembles the surface of a football. The double bonds between the neighbor hexagons are $1.35 \AA$ in length, and the single bonds between the hexagons and the pentagons are $1.47 \AA$ in length. In such a way, the hexa- and pentagonal elements are connected into a conjugated $\pi$-electron system. This fact explains the compact arrangement of carbon atoms, the small size of the $\mathrm{C}_{60}$ molecule, and its properties [11].

The $\mathrm{C}_{60}$ fullerene molecule is an electron acceptor with respect to polymethine squaraine dyes. The val- 


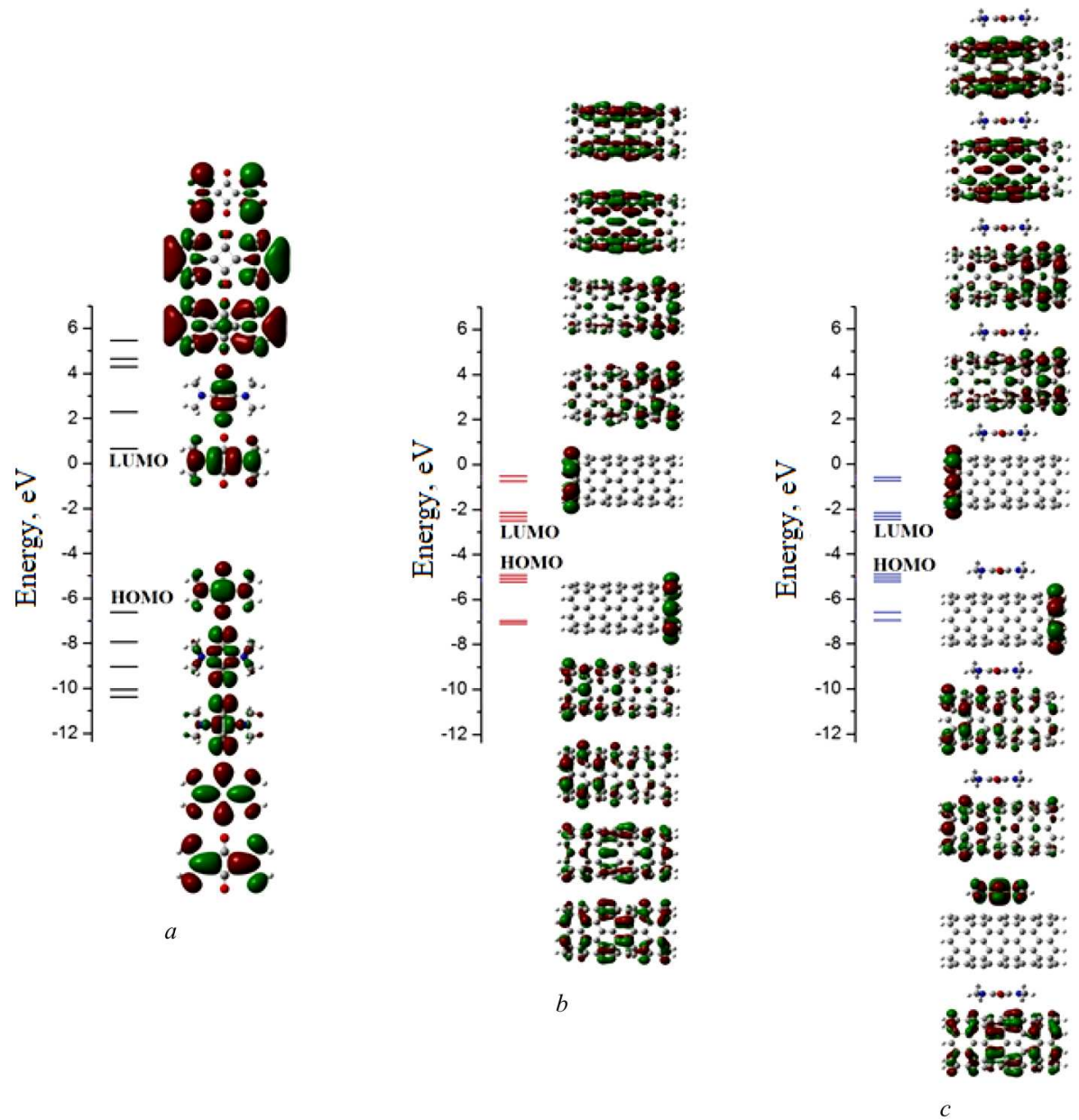

Fig. 6. The distribution of electronic levels and the shapes of molecular orbitals for $\mathrm{C}_{8} \mathrm{~N}_{2} \mathrm{O}_{2} \mathrm{H}_{8}$ dye $(a)$, nanotube $(b)$, and their complex in the energy gap region calculated using the DFT method $(c)$

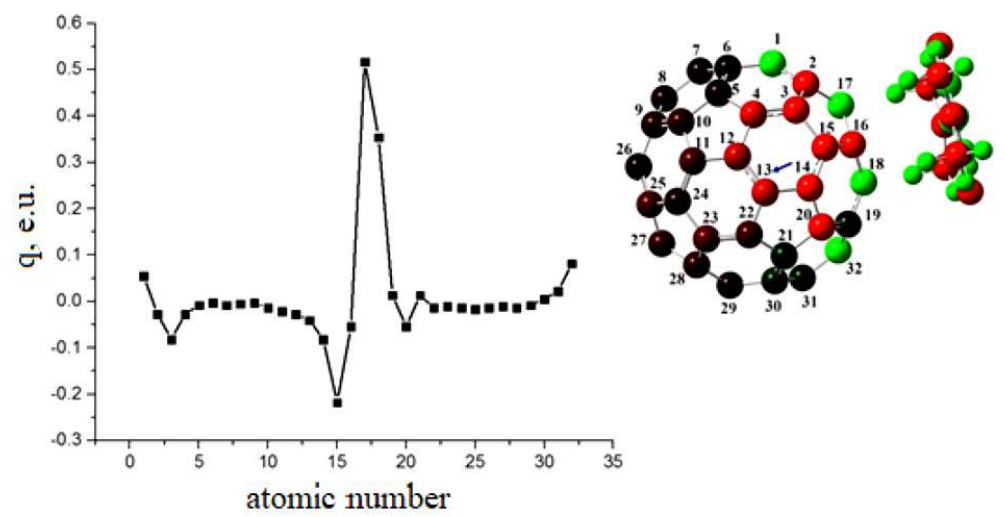

Fig. 7. Charge distribution over the $\mathrm{C}_{60}$ fullerene atoms after the formation of complexes with the dye obtained by the DFT method. The enumeration of atoms is shown in the right panel 


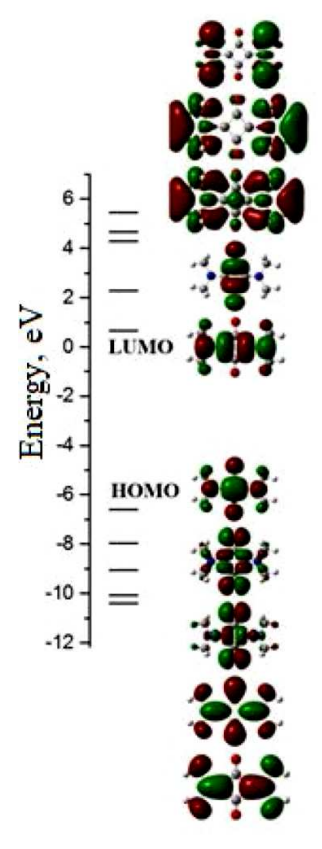

$a$

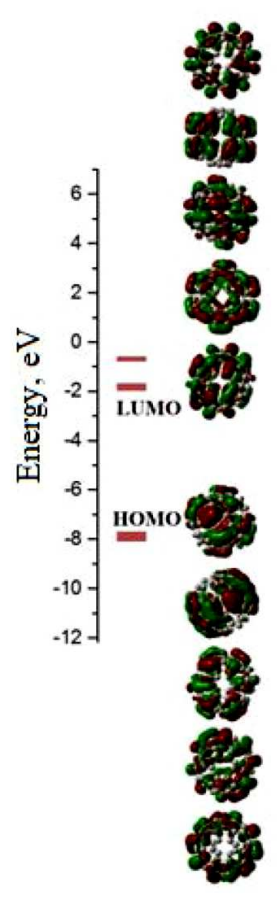

$b$

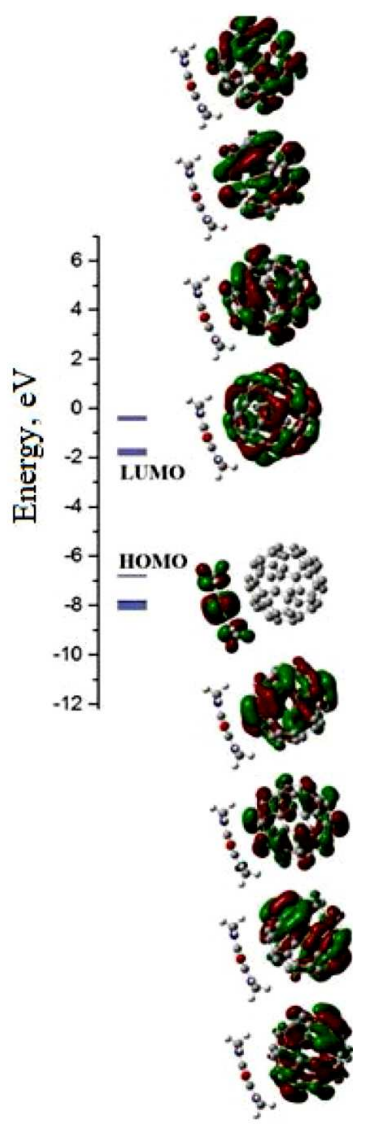

$c$

Fig. 8. The distribution of electronic levels and the shapes of molecular orbitals for $\mathrm{C}_{8} \mathrm{~N}_{2} \mathrm{O}_{2} \mathrm{H}_{8}$ dye $(a)$, fullerene $\mathrm{C}_{60}(b)$, and their complex in the energy gap region calculated using the DFT method $(c)$

ues of its HOMO and LUMO levels calculated using the density functional method with the indicated basis are -7.8 and $-1.8 \mathrm{eV}$, respectively. The results of calculations testify that the charges of carbon atoms equal zero and the dipole moment is absent. At the same time, as the results of a geometry optimization show, the dye in the complex is arranged opposite a six-membered ring of fullerene at a distance of $4 \AA$ (Fig. 7). As a result, the charge distribution changes. The carbon atoms of the fullerene molecule that are located near the dye acquire negative charges and stimulate the charges of other atoms to alternate, with most of the carbon atoms becoming negatively charged, which is confirmed by both methods. As a result, the complex with the dye acquires a dipole moment of $0.2 \mathrm{D}$ (according to the DFT method) or $4.6 \mathrm{D}$ (according to the PM6 method).

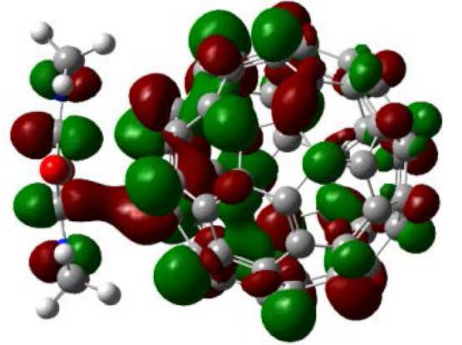

Fig. 9. Molecular orbital LUMO +6 , the electron density of which is localized simultaneously at both components of the complex

The induced charge distribution initiates changes in the fullerene geometry, namely, the lengths of the double and single bonds become different. The charge redistribution also affects the restructuring of elec- 

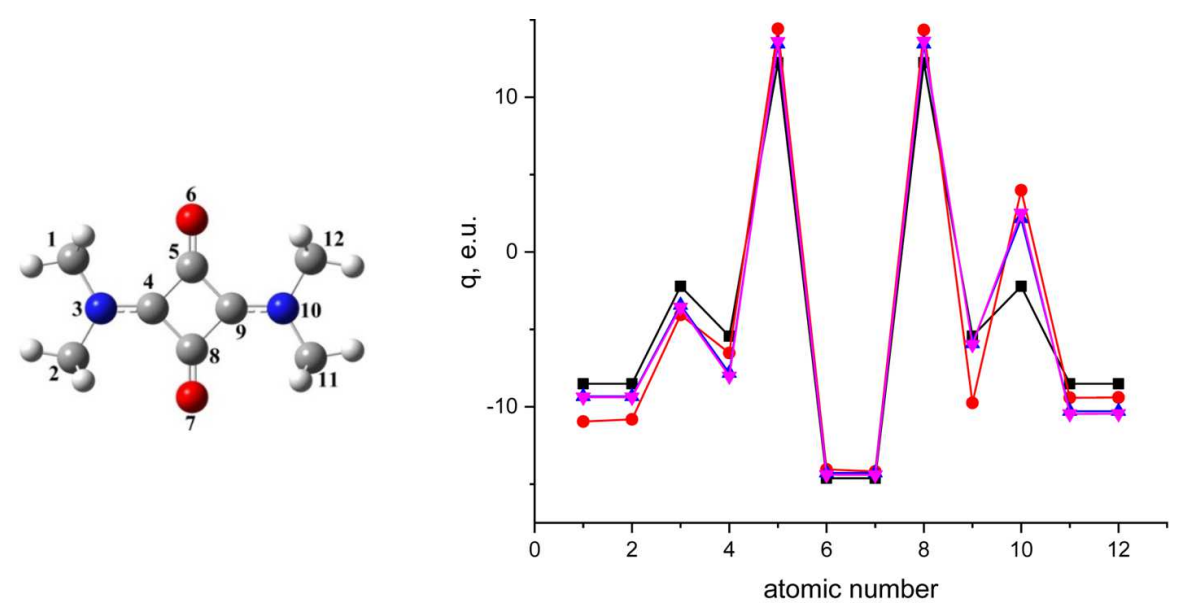

Fig. 10. Charge distributions over the dye molecule (squares) and its complexes with nanotube (solid circles), fullerene (triangles), and graphene (hollow circles) calculated using the PM6 method. The enumeration of atoms in the due molecule is shown in the left panel

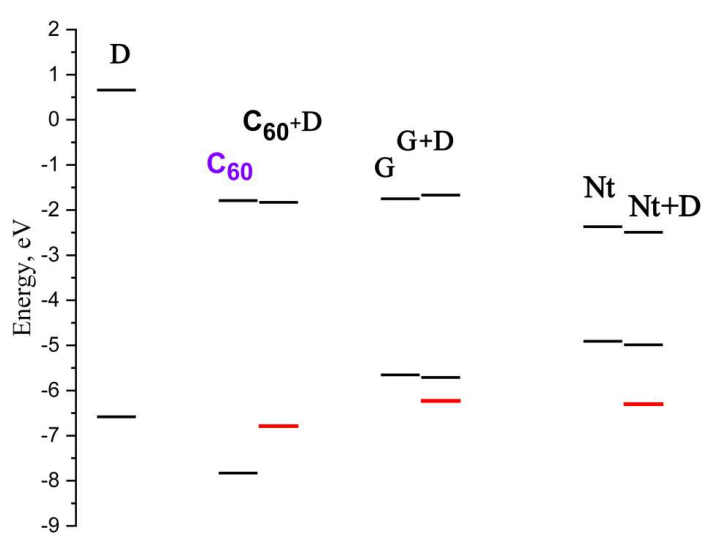

Fig. 11. Energy levels in the energy gap of the squaraine dye molecule (D), fullerene $\mathrm{C}_{60}$, graphene plane $(\mathrm{G})$ and nanotubes $(\mathrm{Nt})$ and in their complexes with the dye: $\mathrm{C}_{60}+\mathrm{D}, \mathrm{G}+\mathrm{D}$, and $\mathrm{Nt}+\mathrm{D}$. The level with the localization of electronic density at the chromophore of the dye is indicated by a light color

tronic levels. As one can see from Fig. 8, the energy gap for the fullerene-dye complex becomes narrower in comparison with the gaps for its individual components owing to the splitting of the degenerate electronic levels in $\mathrm{C}_{60}$.

The HOMO is localized at the dye, the next orbital is the first free one localized at $\mathrm{C}_{60}$. The energy gap shift is maximum in comparison with other carbon structures, being of an order of $1 \mathrm{eV}$. The calculation of excited states shows that just those orbitals make the electron transition with charge transfer possible, which gives the most intense contribution to the absorption spectrum. This transition takes place under the light excitation. As a result, the charge is transferred from the dye to the fullerene. This effect is widely used in organic solar cells.

There also appear orbitals the electronic density of which is simultaneously localized at both complex components (Fig. 9). The energy of such an orbital is $E=0.8 \mathrm{eV}$, and it can also contribute to the optical absorption spectra. The absorption spectrum of the complex composed of the squaraine dye and the fullerene $\mathrm{C}_{60}$ molecules has a maximum at a wavelength of $486 \mathrm{~nm}$.

\subsection{Quantum chemical modeling of the dye properties in complexes with carbon nanoparticles}

It should be noted that the geometry of a dye molecule in the complexes with carbon nanostructures changes at its optimization by both applied methods. In the initial state, i.e. before the interaction, the molecule of the $\mathrm{C}_{8} \mathrm{~N}_{2} \mathrm{O}_{2} \mathrm{H}_{8}$ dye is symmetric, because its atoms have the same charge distribution with respect to the molecular center. Therefore, the dipole moment is zero. According to the results of DFT calculations, the energy corresponding to the excited state (the LUMO) equals $0.8 \mathrm{eV}$, and the energy of the ground state (the HOMO) is $-6.6 \mathrm{eV}$. The calculations also allowed us to determine that the main contribution to the absorption intensity of this molecule is made by the transitions from the HOMO onto the LUMO, which belong to the $\pi$-type orbitals. 
As one can see from Fig. 10, the charge transfer from the dye to carbon nanoparticles occurs almost identically in the cases of fullerene and graphene, which is evidenced by the coincidence of the curves marked by triangles and hollow circles. Before the interaction, nitrogen atom 10 has a negative charge. After the interaction, its charge becomes positive in all cases of carbon nanostructures. This loss of a certain amount of charge, which probably occurs through the charge transfer from the dye to the carbon nanostructures, is reflected on the other atoms, because the electron system is conjugate.

After the excitation of the dye molecule at the corresponding wavelength, the electronic transition HOMO-LUMO is realized. At the relaxation, if there is the acceptor LUMO from the carbon nanostructure near the dye, the electron can transit onto this molecular orbital. As one can see from Fig. 11, it is energetically advantageous for an electron from the dye to return onto the level of fullerene, graphene, or nanotubes.

The formation of complexes results in a certain shift of the dye levels (Table 1, 2). For instance, for the free dye, the HOMO energy is $-6.6 \mathrm{eV}$. In the complex with fullerene, this orbital remains to be the HOMO, but its energy decreases to $-6.8 \mathrm{eV}$. In the case of interaction with the nanotube, the energy of this orbital rises to $-6.3 \mathrm{eV}$, but it becomes built into the electronic structure of the nanotube and ceases to be highest occupied orbital, but the HOMO-3 (the HOMO-2 in the case of graphene), and its energy also increases to $-6.2 \mathrm{eV}$. The calculations of the electronic transition spectra for the complexes show that the dye absorption will shift toward the red region. In

Table 1. Energies of the HOMO and LUMO levels in complexes and their components

\begin{tabular}{|l|c|c|c|c|c|c|c|}
\hline \multicolumn{1}{|c|}{ Energy } & $\mathrm{D}$ & $\mathrm{C}_{60}$ & $\mathrm{Nt}$ & $\mathrm{G}$ & $\mathrm{D}+\mathrm{C}_{60}$ & $\mathrm{D}+\mathrm{Nt}$ & $\mathrm{D}+\mathrm{G}$ \\
\hline LUMO, eV & 0.7 & -1.8 & -2.4 & -1.75 & -1.8 & -2.5 & -1.7 \\
HOMO, eV & -6.6 & -7.8 & -4.9 & -5.65 & -6.8 & -4.9 & -5.7 \\
$\mathrm{E}, \mathrm{eV}$ & 7.2 & 6 & 2.6 & 3.9 & 5 & 2.5 & 4 \\
\hline
\end{tabular}

Table 2. The HOMO level of the dye

in a separate molecule and its complexes, eV

\begin{tabular}{|c|c|c|c|}
\hline $\mathrm{D}$ & $\mathrm{D}+\mathrm{C}_{60}$ & $\mathrm{D}+\mathrm{Nt}$ & $\mathrm{D}+\mathrm{G}$ \\
\hline-6.6 & -6.8 & -6.3 & -6.2 \\
\hline
\end{tabular}

ISSN 2071-0194. Ukr. J. Phys. 2020. Vol. 65, No. 9 particular, if, according to calculations, the dye absorbs at $340 \mathrm{~nm}$, then the absorption will be maximum at $486 \mathrm{~nm}$ for its complex with fullerene and at $644 \mathrm{~nm}$ for its complex with graphene. Such considerable changes in the energy gap of those complexes in comparison with the gaps of their individual components are associated with differences in the electronic structure of carbon nanostructures.

\section{Conclusions}

In all complexes of the squaraine dye with carbon nanoparticles (fullerene, graphene, nanotube), the charge transfer from the dye to the carbon nanoparticles takes place. Owing to the charge redistribution over the nanoparticle surface, the geometry of nanoparticles changes. For instance, for the fullerene molecule, this results in a decrease of its symmetry, the appearance of a dipole moment, and the restructuring of electronic levels.

The electronic levels of carbon nanoparticles in the complexes become shifted, and the energy gap is reduced (by $0.1 \mathrm{eV}$ for the dye-graphene and dye-nanotube complexes). In the case of fullerene, the gap reduction by $1 \mathrm{eV}$ takes place owing to the splitting of the degenerate $\mathrm{C}_{60}$ levels and the appearance of molecular orbitals localized simultaneously at the both components of the complexes. Variations in the energy gap of complexes are associated with the differences in the electronic structure of carbon nanoparticles.

The HOMO level of the dye, which provides the main contribution to the absorption spectra of the complexes, shifts depending on the nanoparticle shape, and this shift leads to a shift of the absorption spectrum toward the red side.

1. R.A. Ristinen, J.J. Kraushaar. Energy and the Environment (Wiley, 2006).

2. S. Khan, A.A. Edathil, F. Banat. Sustainable synthesis of graphenebased adsorbent using date syrup. Sci. Rep. 9, 18106 (2019).

3. J.K. Rath. Low temperature polycrystalline silicon: A review on deposition, physical properties and solar cell applications. Sol. Energ. Mater. Sol. Cells 76, 431 (2003).

4. X. Liu, P.R. Coxon, M. Peters, B. Hoex, J.M. Cole, D.J. Fray. Black silicon: Fabrication methods, properties and solar energy applications. Energ. Environ. Sci. 7, 3223 (2014).

5. W.H. Bloss, F. Pfisterer, M. Schubert, T. Walter. Thin-film solar cells. Prog. Photovoltaics 3, 3 (1995).

6. A. Shah, P. Torres, R. Tscharner, N. Wyrsch, H. Keppner. Photovoltaic technology: The case for thin-film solar cells. Science 285, 692 (1999). 
7. K.L. Chopra, P.D. Paulson, V. Dutta. Thin-film solar cells: An overview. Prog. Photovoltaics 12, 69 (2004).

8. M.K. Nazeeruddin, P. Pechy, T. Renouard, S.M. Zakeeruddin, R. Humphry-Baker, P. Comte, P. Liska, L. Cevey, E. Costa, V. Shklover, L. Spiccia, G.B. Deacon, C.A. Bignozzi, M. Grätzel. Engineering of efficient panchromatic sensitizers for nanocrystalline $\mathrm{TiO}_{2}$-based solar cells. J. Am. Chem. Soc. 123, 1613 (2001).

9. H. Wang, Y.H. Hu. Graphene as a counter electrode material for dye-sensitized solar cells. Energ. Environ. Sci. 5, $8182(2012)$.

10. J.G. Nam, Y.J. Park, B.S. Kim, J.S. Lee. Enhancement of the efficiency of dyesensitized solar cell by utilizing carbon nanotube counter electrode. Scripta Mater. 62, 148 A150 (2010).

11. T.L. Makarova. Electrical and optical properties of monomer and polymerized fullerenes. Fiz. Tekh. Poluprovodn. 35, 257 (2001) (in Russian).

12. A.Yu. Belik, A.Yu. Rybkin, I.I. Voronov, N.S. Goryachev, D. Volyniuk, J.V. Grazulevicius, P.A. Troshin, A.I. Kotelnikov. Non-covalent complexes of polycationic fullerene $\mathrm{C}_{60}$ derivative with xanthene dyes - Spectral and photochemical properties in water and in liposomes. Dyes Pigm. 139, 65 (2017).

13. G. Chen, D. Yokoyama, H. Sasabe, Z. Hong, Y. Yang, J. Kido. Optical and electrical properties of a squaraine dye in photovoltaic cells. Appl. Phys. Lett. 101, 083904 (2012).

14. M.A.M. Al-Alwani, A.B. Mohamad, N.A. Ludin, Abd. A.H. Kadhum, K. Sopian. Dye-sensitised solar cells: Development, structure, operation principles, electron kinetics, characterisation, synthesis materials and natural photosensitisers. Ren. Sust. En. Rev. 650, 183 (2016).

15. O.A. Kyzyma, M.V. Korobov, M.V. Avdeev, V.M. Garamus, V.I. Petrenko, V.L. Aksenov, L.A. Bulavin. Solvatochromism and fullerene cluster formation in $\mathrm{C}_{60} / \mathrm{N}$ methyl-2-pyrrolidone. Fulleren. Nanotub. Carbon Nanostrust. 18, 458 (2010).

16. O.A. Kyzyma, T.O. Kyrey, M.V. Avdeev, M.V. Korobov, L.A. Bulavin, V.L. Aksenov. Non-reversible solvatochromism in N-methyl-2-pyrrolidone/toluene mixed solutions of fullerene $\mathrm{C}_{60}$. Chem. Phys. Lett. 556, 178 (2013).

17. P.A. Troshin, R.N. Lubovskaya. Organic chemistry of fullerenes: the major reactions, types of fullerene derivatives and prospectrs for their practical use. Rus. Chem. Rev. 77, 305 (2008).

18. J.L. Bricks, A.D. Kachkovskii, Y.L. Slominskii, A.O. Gerasov, S.V. Popov. Molecular design of near infrared polymethine dyes: A review. Dyes.Pigm. 121, 238 (2015).

19. G. Patonay, J. Salon, J. Sowell, L. Strekowski. Noncovalent labeling of biomolecules with red and near-infrared dyes. Molecules 9, 40e9 (2004).
20. M. J. Frisch, G.W. Trucks, H.B. Schlegel, G.E. Scuseria, M.A. Robb, J.R. Cheeseman, Jr., J.A. Montgomery, T. Vreven, K.N. Kudin, J.C. Burant, J.M. Millam, S.S. Iyengar, J. Tomasi, V. Barone, B. Mennucci, M. Cossi, G. Scalmani, N. Rega, G.A. Petersson, H. Nakatsuji, M. Hada, M. Ehara, K. Toyota, R. Fukuda, J. Hasegawa, M. Ishida, T. Nakajima, Y. Honda, O. Kitao, H. Nakai, M. Klene, X. Li, J.E. Knox, H.P. Hratchian, J.B. Cross, C. Adamo, J. Jaramillo, R. Gomperts, R.E. Stratmann, O. Yazyev, A.J. Austin, R. Cammi, C. Pomelli, J.W. Ochterski, P.Y. Ayala, K. Morokuma, G.A. Voth, P. Salvador, J.J. Dannenberg, V.G. Zakrzewski, S. Dapprich, A.D. Daniels, M.C. Strain, O. Farkas, D.K. Malick, A.D. Rabuck, K. Raghavachari, J.B. Foresman, J.V. Ortiz, Q. Cui, A.G. Baboul, S. Clifford, J. Cioslowski, B.B. Stefanov, G. Liu, A. Liashenko, P. Piskorz, I. Komaromi, R.L. Martin, D.J. Fox, T. Keith, M.A. Al-Laham, C.Y. Peng, A. Nanayakkara, M. Challacombe, P.M.W. Gill, B.Johnson, W. Chen, M.W. Wong, C. Gonzalez, J.A. Pople. Gaussian 03, Revision A.1 (Gaussian Inc., 2003).

21. O.L. Pavlenko, V.A. Brusentsov, M.P. Kulish, O.P. Dmytrenko, V.A. Sendiuk, P.Yu. Kobzar, V.V. Strelchuk, Yu.L. Slominskyi, V.V. Kurdiukov, O.D. Kachkovskyi, Ya.U. Prostota. Spectral and quantum chemical study of interaction between fullerenes and squaraine dyes. Nanosyst. Nanomat. Nanotekhnol. 13, 1 (2018) (in Ukrainian).

22. A.M. Zarytska, V.A. Brusentsov, O.L. Pavlenko. M.P. Kulish, O.P. Dmytrenko, O.D. Kachkovskyi. Electronic structure of molecular system fullerene- $\mathrm{C}_{60}$ with indopentacyanine dye with stack and covalent interaction. Nanosyst. Nanomat. Nanotekhnol. 15, 507 (2017) (in Ukrainian). Received 02.04.20. Translated from Ukrainian by O.I. Voitenko

О. Павленко, О. Дмитренко, М. Куліш, А. Гапонов, Н. Оберніхіна, О. Качковсъкий, О. Ілъченко, Л. Булавін

КВАНТОВО-ХІМІЧНЕ МОДЕЛЮВАННЯ КОМПЛЕКСІВ СКВАРАЇНОВИХ БАРВНИКІВ З ВУГЛЕЦЕВИМИ НАНОЧАСТИНКАМИ: ГРАФЕНОМ, НАНОТРУБКОЮ, ФУЛЕРЕНОМ

Р е $з$ ю м е

Досліджено будову та електронну структуру комплексів барвників, що містять різну кількість електронодонорних атомів кисню з вуглецевими наноструктурами в залежності від їх розмірності (фулерен $\mathrm{C}_{60}$, вуглецева нанотрубка, графен). Встановлено, що у результаті перенесення заряду від барвників до вуглецевих наночастинок відбуваються зміни геометрії вуглецевих наноструктур та хромофорів барвників, а також електронної будови комплексів. 